

\title{
Methodological improvements for investigating silcrete formation: petrography, FT-IR and oxygen isotope ratio of silcrete quartz cement, Lake Eyre Basin (Australia)
} Anne Alexandre, Jean-Dominique Meunier, Emmanuelle Llorens, Steve M Hill, Samuel M Savin

\section{To cite this version:}

Anne Alexandre, Jean-Dominique Meunier, Emmanuelle Llorens, Steve M Hill, Samuel M Savin. Methodological improvements for investigating silcrete formation: petrography, FT-IR and oxygen isotope ratio of silcrete quartz cement, Lake Eyre Basin (Australia). Chemical Geology, 2004, 211 (3-4), pp.261-274. 10.1016/j.chemgeo.2004.06.024 . hal-01909690

\section{HAL Id: hal-01909690 https://hal.science/hal-01909690}

Submitted on 14 Dec 2018

HAL is a multi-disciplinary open access archive for the deposit and dissemination of scientific research documents, whether they are published or not. The documents may come from teaching and research institutions in France or abroad, or from public or private research centers.
L'archive ouverte pluridisciplinaire $\mathbf{H A L}$, est destinée au dépôt et à la diffusion de documents scientifiques de niveau recherche, publiés ou non, émanant des établissements d'enseignement et de recherche français ou étrangers, des laboratoires publics ou privés. 


\title{
Methodological improvements for investigating silcrete formation: petrography, FT-IR and oxygen isotope ratio of silcrete quartz cement, Lake Eyre Basin (Australia)
}

\author{
Anne Alexandre ${ }^{\mathrm{a}, *}$, Jean-Dominique Meunier ${ }^{\mathrm{a}}$, Emmanuelle Llorens $^{\mathrm{a}}$ \\ Steve M. Hill ${ }^{\mathrm{b}}$, Samuel M. Savin ${ }^{\mathrm{c}}$ \\ ${ }^{a}$ CNRS, CEREGE, Université Aix-Marseille III, Europôle de l'Arbois, BP 80, 13545 Aix en Provence Cedex 04, France \\ ${ }^{\mathrm{b}}$ Cooperative Research Centre for Landscape Environments and Mineral Exploration. The University of Canberra, \\ Canberra, ACT, 2601, Australia \\ ${ }^{\mathrm{c} D e p a r t m e n t}$ of Geological Sciences, Case Western Reserve University, Cleveland, OH 44106, USA
}

Received 7 August 2003; accepted 21 June 2004

\begin{abstract}
The oxygen isotopic composition $\left(\delta^{18} \mathrm{O}\right)$ of the cement of a silcrete sample from the "Cordillo silcrete" (Late Eocene/Early Oligocene) of Lake Eyre Basin (Australia) was investigated. The massive structure of the silcrete outcrop and the absence of pedogenic features suggest that this silcrete formed by precipitation from groundwater. In order to avoid errors inherent in estimates of the cement $\delta^{18} \mathrm{O}$ value from isotopic analyses of bulk material and mass balance considerations, methodological improvements are described. The silcrete cement is physically separated from the detrital phases. Its purity is checked using cathodoluminescence (CL) spectroscopy. Optical microscopy, X-ray diffraction (XRD) analyses, and Fourier transform infrared (FT-IR) spectroscopy show the cement is made of three phases: (i) overgrowth; (ii) crypto-crystalline quartz; and (iii) microcrystalline quartz. Thus, its $\delta^{18} \mathrm{O}$ value must be interpreted as that of a mixture, although the mixture consists mainly of cryptocrystalline quartz. As the amount of $\mathrm{Si-OH}-\mathrm{O}$-xchangeable oxygen in the cement would bias the results by an amount less than the analytical error $(0.09 \%)$, it is unnecessary to go through an equilibration procedure prior to isotopic analysis. The $\delta^{18} \mathrm{O}$ value of the cement sample is between $24.8 \%$ and $25.8 \%$ relative to V-SMOW. Assuming an Eocene/Oligocene temperature of $15-20{ }^{\circ} \mathrm{C}$, in agreement with published regional temperature estimates, the inferred $\delta^{18} \mathrm{O}$ value of the quartz-forming solution was between $-6.9 \%$ and $-12.2 \%$. This is lower than the minimum $\delta^{18} \mathrm{O}$ value of $-6.70 \%$ estimated for the modern groundwater near the sample site. A plausible paleoenvironmental scenario is that silcrete formed in a climate colder and wetter than the modern one, from shallow groundwater frequently recharged, in a setting of slow tectonic uplift.
\end{abstract}

(C) 2004 Elsevier B.V. All rights reserved.

Keywords: Australia; Silcrete; Quartz cement; Oxygen isotopes; Infrared spectroscopy; Tertiary

* Corresponding author. Tel.: +33 4429715 54/17-54; fax: +33 442971540 .

E-mail address: alexandre@cerege.fr (A. Alexandre). 


\section{Introduction}

Silcrete is commonly described as an indurated regolith, composed mainly of detrital quartz clasts in a cement of authigenic opal, chalcedony or microcrystalline quartz (Singh et al., 1992). Silcrete outcrops occur widely in present-day dry areas that are subject to denudation and did not undergo Tertiary and Quaternary glacial erosion. Areas in which silcretes are common include parts of inland Australia (e.g., Langford-Smith, 1978), Egypt (Abdel-Wahab et al., 1998), southern Africa (Smale, 1973; Summerfield, 1983a,b; Nash et al., 1994) and northern Canada (Ross and Chiarenzelli, 1985).

Three main processes have been proposed in the literature for silcrete formation (Thiry and Milnes, 1991; Abdel-Wahab et al., 1998; Webb and Golding, 1998).

(1) Pedogenic silcrete-precipitation from downward moving soil solutions. Silcrete may form at surface temperature, under conditions of alternating wet and dry periods, during which silica and other cations are leached from the upper part of the soil profile, and then precipitate at depth (Watts, 1978; Thiry and Milnes, 1991, Thiry and Simon-Coinçon, 1996).

(2) Groundwater silcrete-deposition from upward-moving groundwater. Groundwater deposition of silcrete is a low temperature process, resulting from the combination of significant water chemistry fluctuations and high evaporation rates. Siliceous rocks are leached at depth and the resulting silica-rich solutions move upward through the soil, regolith, or sediment, as the result of capillary processes. All major cations except titanium and silicon are lost at the surface, and precipitation of silica within the soil creates the silcrete. (Thiry and Milnes, 1991; Rodas et al., 1994; Abdel-Wahab et al., 1998; Webb and Golding, 1998).

(3) Hdyrothermal silcrete-formation at temperature higher than soil temperature. In this case, the silica cement is derived from formation waters or basinal brines (Canals and Meunier, 1995; Graham et al., 1996).

In inland Australia, most thick silcrete crusts are associated with the characteristic mesa and plateau topography. They are especially widespread in the Lake Eyre Basin, which is the fourth largest internal basin in the world. These silcretes have been referred to as "Cordillo silcretes" because they are located mainly on the upper "Cordillo depositional surface" (Late Eocene-Early Oligocene surface) (Wopfner, 1978; Alley, 1998; Croke et al., 1998). These silcretes have been interpreted as having formed by precipitation of silica from downward-moving soil solutions and/or upward-moving groundwater.

No geochronologic techniques are available for the accurate dating of silcretes (Watchman and Twidale, 2002). Thus, it has not been possible to place the interval of silcrete formation within the established climatic history of Inland Australia and evaluate the nature of the climate, at the time of silcrete cementation (review in Nash et al., 1994). As active silcrete formation at the present time has not been documented, it is not possible to infer the conditions of formation of fossil silcretes by analogy with modern ones.

In the present study, the oxygen isotopic composition of the silica cement of a silcrete sample from the "Cordillo silcrete" of the Lake Eyre Basin (South Australia) has been investigated. The oxygen isotopic composition of a mineral reflects both the temperature and the isotopic composition of the solution from which it precipitated (Graham et al., 1996). Thus, oxygen isotope analysis of silcrete cement may help to constrain the temperature of silcrete formation and/or the source of water (e.g., meteoric, hydrothermal) from which the cement formed. This study was based on the analysis of a single sample. Its main purpose is to put forward a methodological approach to better understand silcrete formation and associated paleoenvironments, not to provide an interpretation of the formation of the entire "Cordillo silcrete" group.

Two oxygen isotope studies of silcrete have been recently published (Abdel-Wahab et al., 1998; Webb and Golding, 1998). In these studies the oxygen isotopic compositions of detrital quartz and bulk silcrete samples were measured. The oxygen isotopic composition of pure silcrete cement was calculated from mass balance calculations based upon the proportions of detrital and authigenic silica. The latter was estimated either from point-counting of thin sections (Abdel-Wahab et al., 1998) or from concentrations of $\mathrm{Zr}$ in a sample suite (Webb and Golding, 1998). These mass balance approaches lead to unavoidably large uncertainties in the calculated oxygen isotopic composition of the cement. Silcrete 
cement may also be mineralogically and isotopically heterogeneous, and may include micro- or macrocrystalline quartz; hydrated Si oxides (e.g., opal, chalcedony) (Wopfner, 1978; Thiry and Milnes, 1991; Singh et al., 1992; Webb and Golding, 1998); and Ti-, Al- and Fe oxides (Hutton et al., 1978; Wopfner, 1978; Summerfield, 1983a,b; Taylor and Ruxton, 1987). Each of those phases may fractionate oxygen isotopes differently with respect to water. Additionally, in hydrated silica, which is common in silcrete cement, isotopic exchange between $\mathrm{Si}-\mathrm{O}$ bonds and hydroxyl groups (which are readily exchangeable with ambient water), may occur in the laboratory during dehydration prior to oxygen isotope analysis (Labeyrie and Juillet, 1982; Webb and Longstaffe, 2000). To minimize the effect of this on the measured $\delta^{18} \mathrm{O}$ values, isotopic equilibration of hydroxyl groups with $\mathrm{H}_{2} \mathrm{O}$ under controlled conditions must precede extraction of oxygen for analysis (Labeyrie and Juillet, 1982; Haimson and Knauth, 1983). This was not done in the studies of bulk samples by Abdel-Wahab et al. (1998) and Webb and Golding (1998).

This paper describes methodological improvements, in the analysis of silcrete cement. In order to minimize the problems described above, we have physically separated the silcrete cement from the detrital phases using the method of Lee and Savin (1985). We have then studied cement chemistry and mineralogy through optical microscopy, X-ray diffraction, and bulk chemical analyses. The purity of the extracted cement is checked using cathodoluminescence spectroscopy. Fourier-Transform Infra-Red spectroscopy is used to estimate the proportion of exchangeable oxygen in the hydrated silica phase of the cement.

\section{Environmental context and location}

The "Cordillo silcrete" sample $\left(27.72^{\circ} \mathrm{S}, 140.76^{\circ} \mathrm{E}\right.$, $-25 \mathrm{~m}$ a.s.1.) was collected from a massive silcrete outcrop located near the town of Innamincka (northern South Australia) (Fig. 1). The site is located in an arid to semi-arid region covered by shrublands, shrub-steppes and grasslands (Christophel and Greenwood, 1989).

Climatic data based on a standard 30-year period (from 1961 to 1990) are available from the Australian
Bureau of Meteorology for Oodnadatta $\left(27.55^{\circ} \mathrm{S}\right.$, $135.44^{\circ} \mathrm{E}, 116.5 \mathrm{~m}$ ), approximately $500 \mathrm{~km}$ west of Innamincka and $90 \mathrm{~m}$ higher (Fig. 1). Rainfall occurs predominantly in the summer and averages $398 \mathrm{~mm}$ year $^{-1}$. Mean annual temperature is in the range of 21-24 ${ }^{\circ} \mathrm{C}$. Median daily soil temperature is $26{ }^{\circ} \mathrm{C}$ at $50 \mathrm{~cm}$ depth, and $26.8^{\circ} \mathrm{C}$ at $100 \mathrm{~cm}$ depth (Australian Bureau of Meteorology).

The age of the "Cordillo silcrete" group is estimated to be Late Eocene to Oligocene. It occurs above the Eyre Formation (Paleocene-Eocene) and below the Etadunna and equivalent formations (Late Oligocene-Middle Miocene) (Wopfner, 1978; Alley, 1998; Croke et al., 1998).

The Eyre Formation was deposited in a fluvial regime with a depocentre located to the northeast of the current Eyre basin depocentre; the Etadunna Formation is a lacustrine facies with a depocentre to the west. Slow tectonic uplift of the northern part of the modern Lake Eyre basin occurred between the two depositional phases and extended the Lake Eyre Basin to the west (Alley, 1998; Croke et al., 1998).

Previous studies suggest that the "Cordillo silcretes" may have developed either: (1) at the expense of the Eyre Formation, during an erosional phase contemporaneous with slow Eocene-Oligocene tectonic uplift (Alley, 1998); or (2) at the expense of Etadunna-Mirikata Formation, due to evaporation of saline groundwaters during the Oligocene-Miocene (Webb and Golding, 1998).

\section{Methods}

\subsection{Mineralogical analyses and observations under optical and cathodoluminescence microscopes}

The different minerals comprising the cement were identified and quantified using optical microscopy, Xray diffraction (XRD) analysis, and inductively coupled plasma-atomic elemental spectrometry (ICPAES) analysis. Particular attention was paid to the presence of multiple cement zones.

Detrital quartz clasts were distinguished from overgrowth and quartz-cement using a cathodoluminescence (CL) Scanning Electron Microscope (SEM) Jeol JMS 840 at the Geology Institute of Strasbourg (France) (Llorens, 1999). Detrital high-temperature 


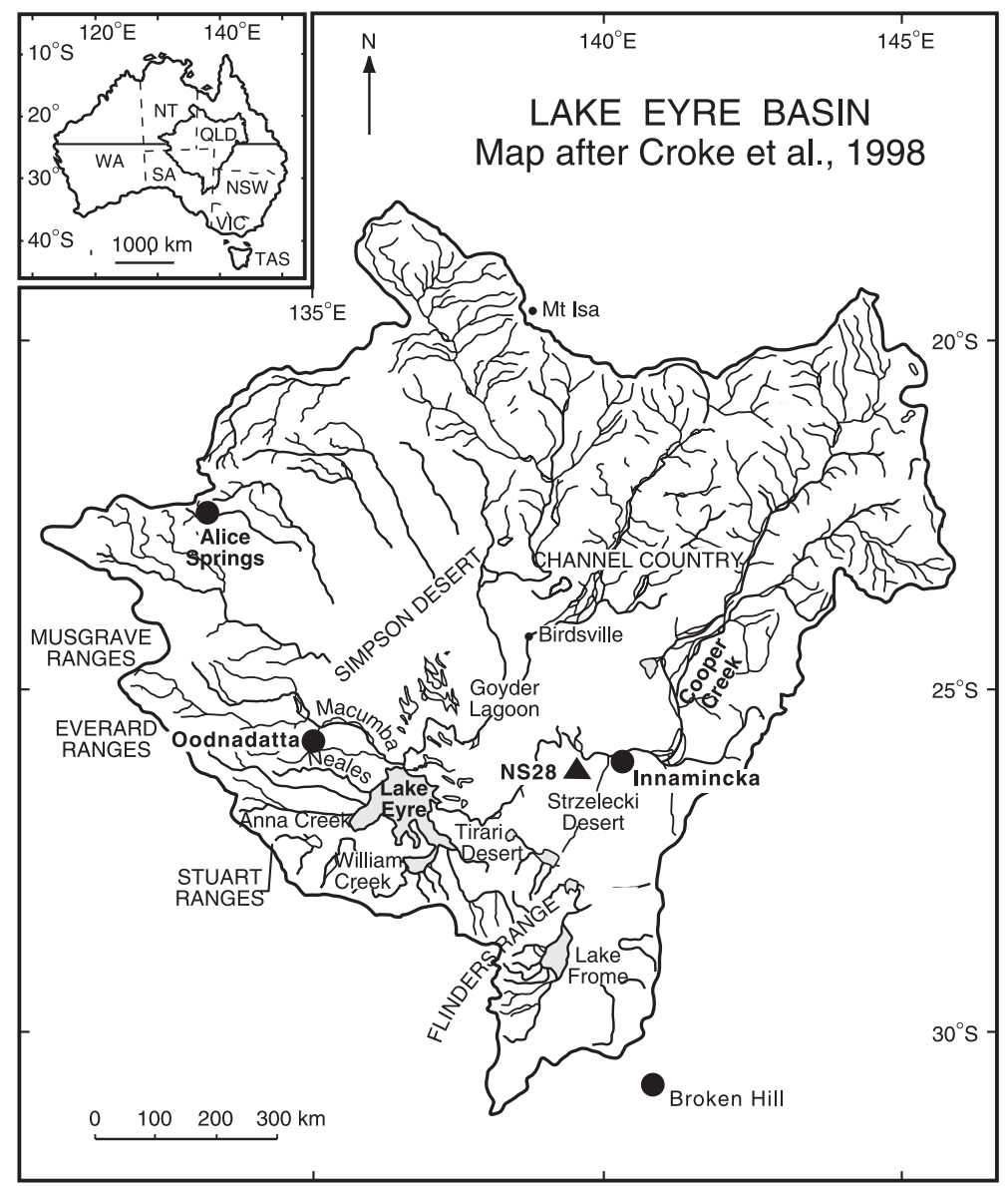

Fig. 1. Location of the sampled silcrete NS $28\left(27.72^{\circ} \mathrm{S}, 140.76^{\circ} \mathrm{E},-25 \mathrm{~m}\right.$ a.s.l.), in Lake Eyre Basin, South Australia.

quartz typically exhibits bright luminescence, while authigenic low-temperature quartz is typically non- or weakly luminescent (Sprunt and Nur, 1981) (Fig. 2).

Abundance of detrital quartz, authigenic overgrowths, micro-crystalline and crypto-crystalline quartz were estimated by point-counting (2000 points on one thin section) under the optical microscope (Llorens, 1999).

\subsection{Fourier transform infrared (FT-IR) micro-spectrometry analysis of the quartz cement}

Micro- and non-crystalline silica minerals can be classified according to the character of their water of hydration. Molecular water $\left[\left(\mathrm{H}_{2} \mathrm{O}\right)_{\mathrm{mol}}\right]$ consists of adsorbed isolated molecules trapped in cages of the silicate structure, while hydroxyl groups $\left[\left(\mathrm{H}_{2} \mathrm{O}\right)_{\mathrm{SiOH}}\right]$ are involved in hydrogen bonds in cavities of the microstructure and on the surface of crystallites and/or non-crystalline particles (Flörke et al., 1991).

The FT-IR spectrometer was used in order to (1) identify the different mineralogical components of the silcrete cement on the basis of their hydration features and (2) estimate the percentage of exchangeable oxygen in hydroxyl-bearing silicate phases. The later was done to assess the necessity to perform equilibrate the samples with water of known isotopic composition prior to analysis as done by Labeyrie and Juillet (1982).

The FT-IR spectrometer Protégé 460, coupled with an optical microscope Continuum (Nicolet) (University of Aix-Marseille III, France) allows in situ detection of the different $\left(\mathrm{H}_{2} \mathrm{O}\right)_{\mathrm{SiOH}}$ and $\left(\mathrm{H}_{2} \mathrm{O}\right)_{\text {mol }}$ species, with a spatial resolution of $20 \mu \mathrm{m}^{2}$. Spectra 

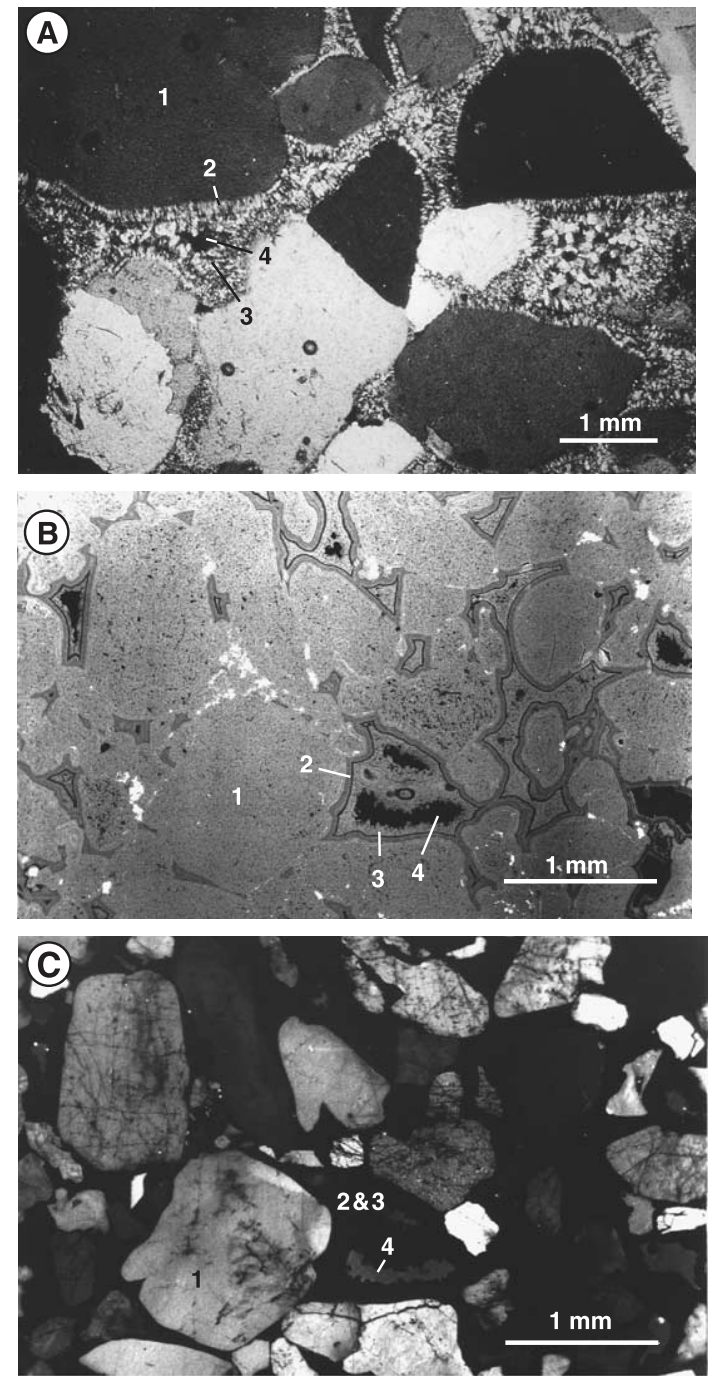

Fig. 2. (A) Photomicrograph (plane polarized light) of the grainsupported fabric silcrete sample, with detrital quartz (1), cryptocrystalline quartz (2), micro-crystalline quartz (3) and voids (4). (B) Secondary electron image of the silcrete sample, with detrital quartz (1), crypto-crystalline quartz (2), micro-crystalline quartz (3) and voids (4). (C) CL-image of the same area showing luminescing detrital quartz (1) surrounded by non-luminescing quartz cement (2 and 3) and voids (4).

are presented in absorbance units at wave numbers between 4000 and $1400 \mathrm{~cm}^{-1}$ (Fig. 3) (Llorens, 1999). Spectra of atmospheric $\mathrm{CO}_{2}$ and $\mathrm{H}_{2} \mathrm{O}$, independently recorded, were subtracted. Each spectrum was processed using the OMNIC program (Thermo Nicolet). Special attention was paid to the spectral region $3500-3700 \mathrm{~cm}^{-1}$ assigned to internal
$\left(\mathrm{H}_{2} \mathrm{O}\right)_{\mathrm{SiOH}}$ stretching vibration. Other relevant spectral regions correspond to the $\left(\mathrm{H}_{2} \mathrm{O}\right)_{\text {mol }}$ stretching band (3000-3500 $\left.\mathrm{cm}^{-1}\right)$, Si-O combination and overtone vibrations $\left(1775-2100 \mathrm{~cm}^{-1}\right)$, and $\left(\mathrm{H}_{2} \mathrm{O}\right)_{\mathrm{mol}}$ and $\mathrm{SiOH}$ bending vibrations $\left(1595-1650 \mathrm{~cm}^{-1}\right)$, (Pironon et al., 2001; Llorens, 1999; Barres, 1990; Langer and Flörke, 1974). Peaks at 1350-1550, 1710 and 2700$3000 \mathrm{~cm}^{-1}$ are assigned to organic group vibrations resulting from carbon coating for S.E.M. analysis.

\subsection{Separation of the fine quartz fraction and concentration of micro- and crypto-quartz}

In an attempt to concentrate the cement phase, size fractionation of the sample was done at the Department of Geological Sciences at Case Western Reserve University (Cleveland, OH, USA), following a procedure developed by Lee and Savin (1985), and later used by Girard and Deynoux (1991) and Graham et al. (1996) for separating diagenetic overgrowths from detrital quartz in quartz-cemented sandstones. The sample was gently ground in water to preserve as much as possible of the original grain size of constituents. Amorphous material was removed by boiling in $5 \mathrm{~N} \mathrm{HCl}$ until the solution became clear. The sample was treated with $7 \% \mathrm{HF}$, at room temperature, in an ultrasonic bath, for 6 days in order to weaken the core-cement interfaces, and facilitate the separation of the cement from the detrital grains. After rinsing, microscopic observation revealed the presence of brown coating remaining on the surface of the grains. Therefore, the sample was once more treated with $\mathrm{HCl}$ and $\mathrm{HF}$, as previously described. The purity of the quartz sample was checked under the optical microscope and by XRD. After rinsing the sample was sieved at 850, 360, $250,150,125,63$ and $45 \mu \mathrm{m}$. The $<2-\mu \mathrm{m}$ size fraction was separated by centrifugation, according to Stokes Law.

The finest fraction $(<2 \mu \mathrm{m})$ was mainly composed of authigenic micro-crystalline and crypto-crystalline quartz. This was documented by comparison between secondary electron images and CL images of the $<2$ $\mu \mathrm{m}$ size fraction, acquired using an Oxford Mono CL coupled to a Philips XL 30 SEM at the University of Nancy I (France). More than 600 grains were counted. We verified that luminescence was not related to the size of particles. 


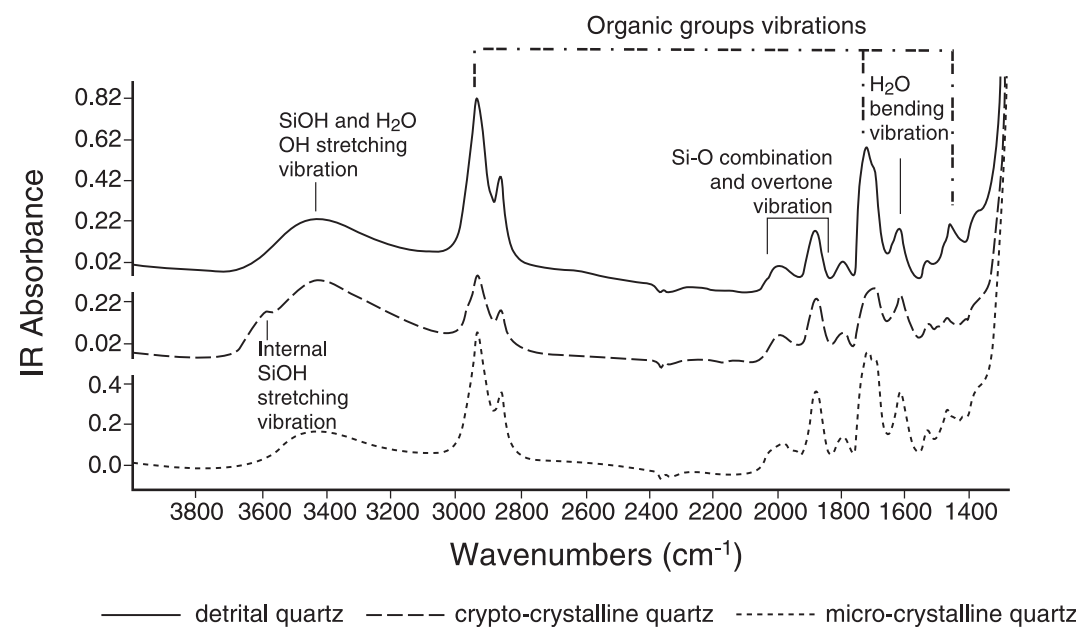

Fig. 3. FT-IR spectra of the silcrete sample: (A) detrital quartz, (B) micro-crystalline quartz and (C) crypto-crystalline quartz.

\subsection{Oxygen isotope analysis}

The oxygen isotopic compositions of the different size fractions were analyzed by a conventional fluorination technique (Clayton and Mayeda, 1963) at the Centre de Recherches Pétrographiques et Géochimiques (Nancy, France): $10 \mathrm{mg}$ of each size fraction was dried at $120{ }^{\circ} \mathrm{C}$ for $1 \mathrm{~h}$, then loaded into a nickel reaction vessel, out-gassed under vacuum at $150{ }^{\circ} \mathrm{C}$ for $2 \mathrm{~h}$ prior to reaction with $\mathrm{BrF}_{5}$ at $550{ }^{\circ} \mathrm{C}$ for $12 \mathrm{~h}$. The liberated $\mathrm{O}_{2}$ was converted to $\mathrm{CO}_{2}$ over hot carbon for mass spectrometric measurement. $\delta^{18} \mathrm{O}$ values are reported in per mil $(\%)$ with respect to the V-SMOW standard. Replicate analyses of a laboratory quartz standard (NL 615; accepted value: $18.4 \pm 0.2)$ yielded an average value of $18.26 \pm 0.09 \%$ ( 7 analyses) over the duration of the study.

\section{Results}

\subsection{Textural features and mineralogical composition of the silcrete sample}

Images of the silcrete sample observed under optical microscope, SEM and CL-SEM are displayed Fig. 2. According to Summerfield' (1983a,b) classification, the silcrete exhibits a grain-supported fabric (Fig. 2A) made of highly luminescent millimeter- to centimeter-size rounded detrital mono-crystalline quartz grains (accounting for $64 \%$ of the rock volume according to point counting). The cement (34\% of the rock volume) is non-luminescent. Voids make up $2 \%$ of the rock volume (Fig. $2 \mathrm{~B}$ and C). The detrital quartz exhibits slightly etched boundaries. Some grains have optically continuous overgrowths of quartz, $10-20 \mu \mathrm{m}$ in width $(4 \%$ of the rock volume). The core overgrowths boundary is highlighted by a brown coating on the detrital grains ( $1 \%$ of the rock volume). The overgrowths do not show any dissolution features or embayments. A 30$\mu \mathrm{m}$-wide zone ( $23 \%$ of the rock volume) surrounds each detrital quartz grain. It shows wrinkle-banding under non-polarized light and parabolic fiber bundles with overlapping boundaries perpendicular to the bands under polarized light, characteristic of cryptocrystalline quartz (with a structure made of crystals too small to be distinguished under optical microscope), also defined as opal-CT (e.g., chalcedony or lussatite) (Flörke et al., 1991). Brown coatings can also be observed in between the crypto-crystalline bands. Micro-quartz with a structure made of crystals large enough to be distinguished under the optical microscope (about $6 \%$ of the rock volume) constitutes the rest of the cement, surrounding the voids. Thus, the silcrete cement is composed of three texturally different phases of authigenic silica (overgrowth, micro-crystalline quartz, crypto-crystalline quartz) which may represent multiple distinct stages in the formation of the cement. The composition of 
the cement-forming fluid (e.g., Si content, salt content, temperature, $\mathrm{pH}$..., etc.) during each of these distinct stages may have been different.

XRD analysis of the bulk silcrete sample detected no minerals other than quartz. The diffraction pattern of the $<2-\mu \mathrm{m}$ fraction is characterized by diffraction peaks characteristic of opal-CT (chalcedony or lussatite) (Chadwick et al., 1987; Flörke et al., 1991; Jones and Segnit, 1971) and quartz, confirming the optical microscopic observations.

Chemical composition of bulk material determined by ICP-AES indicates an $\mathrm{SiO}_{2}$ content of $95 \%$ or greater. $\mathrm{Fe}_{2} \mathrm{O}_{3}$ and $\mathrm{TiO}_{2}$ contents are 0.85 and $0.51 \%$ of the bulk material; $\mathrm{CaO}, \mathrm{MgO}$ and $\mathrm{P}_{2} \mathrm{O}_{5}$ range from $0.004 \%$ to $0.01 \%$ of the bulk material; $\mathrm{MnO}$ and $\mathrm{Na}_{2} \mathrm{O}$ represent $0.004 \%$ and $0.001 \%$, respectively, of the bulk material. $\mathrm{Al}_{2} \mathrm{O}_{3}$ content is under the detection limit of $0.001 \%$. These data imply that the silcrete cement does not contain clay minerals, and suggest that brown coating observed around detrital quartz grains and in between the crypto-crystalline bands is made of iron oxides.

\subsection{Hydration features of the silcrete cement}

Detrital quartz and micro-crystalline quartz show similar FT-IR spectral features: the $\mathrm{OH}$ stretching vibration band of silanol $\left[\left(\mathrm{H}_{2} \mathrm{O}\right)_{\mathrm{SiOH}}\right]$ and molecular water $\left[\left(\mathrm{H}_{2} \mathrm{O}\right)_{\mathrm{mol}}\left(3200-3700 \mathrm{~cm}^{-1}\right)\right]$ have similar shapes and the ratios $\left[\left(\mathrm{H}_{2} \mathrm{O}\right)_{\mathrm{SiOH}}\right.$ and mol area $(3200-$ $\left.3700 \mathrm{~cm}^{-1}\right) / \mathrm{Si}-\mathrm{O}$ area $\left.\left(1775-2100 \mathrm{~cm}^{-1}\right)\right]$ in the two materials are equivalent. An additional internal $\left(\mathrm{H}_{2} \mathrm{O}\right)_{\mathrm{SiOH}}$ stretching vibration peak centered at 3590 $\mathrm{cm}^{-1}$ can be seen in the spectrum of crypto-crystalline quartz (Fig. 3).

According to Langer and Flörke (1974), cryptocrystalline quartz can be characterized by higher total water $\left(\right.$ wt. $\%\left(\mathrm{H}_{2} \mathrm{O}\right)_{\mathrm{SiOH}}$ and mol $)$ than crystalline quartz, but by lower content of $\left.\mathrm{H}_{2} \mathrm{O}\right)_{\mathrm{SiOH}}$ than amorphous opal.

In order to differentiate the cement phases of the silcrete, we integrated the $\left(\mathrm{H}_{2} \mathrm{O}\right)_{\mathrm{SiOH}}$ stretching band (3500-3700 $\left.\mathrm{cm}^{-1}\right)$ and the $\left(\mathrm{H}_{2} \mathrm{O}\right)_{\text {mol }}$ stretching band $\left(3000-3500 \mathrm{~cm}^{-1}\right)$. The ratio of the areas of the $\left(\mathrm{H}_{2} \mathrm{O}\right)_{\mathrm{SiOH}}$ to $\left(\mathrm{H}_{2} \mathrm{O}\right)_{\text {mol }}$ peaks, is proportional to the concentration ratio wt. $\%\left(\mathrm{H}_{2} \mathrm{O}\right)_{\mathrm{SiOH}} / \mathrm{wt} . \%\left(\mathrm{H}_{2} \mathrm{O}\right)$. This ratio equals 0 for both detrital quartz and microcrystalline quartz. It reaches 0.034 for crypto- crystalline quartz. This value is close to the value calculated for opal-CT (0.02) from Langer and Flörke (1974) and significantly lower than that of amorphous opal (0.1-0.7) (calculated from Langer and Flörke, 1974).

To our knowledge, this documents for the first time, the structural difference between crypto-crystalline quartz and micro-crystalline quartz within the cement; a difference also inferred from microscopic observation.

It also indicates that although hydroxyl-bearing crypto-crystalline quartz makes up $70 \%$ of the silcrete cement (and 23\% of the total silcrete sample), hydroxyl groups (wt. $\left.\%\left(\mathrm{H}_{2} \mathrm{O}\right)_{\mathrm{SiOH}}\right)$ account only for about $3 \%$ of the total water $\left(w t . \%\left(\mathrm{H}_{2} \mathrm{O}\right)_{\mathrm{SiOH}}\right.$ and mol $)$ of the cryptocrystalline phase. In other terms, the percentage of exchangeable oxygen, or wt. $\%\left(\mathrm{H}_{2} \mathrm{O}\right)_{\mathrm{SiOH}}$ is only $0.132 \%$ of the oxygen of the crypto-crystalline cement and about $0.09 \%$ of the oxygen of the bulk cement (with a ratio crypto-crystalline quartz/bulk cement, in volume, equals to 0.70 ).

$$
\begin{aligned}
\mathrm{O}_{\mathrm{ex}}= & \left(\left(\mathrm{H}_{2} \mathrm{O}\right)_{\text {sum }} / 100 \cdot\left(\mathrm{H}_{2} \mathrm{O}\right)_{\mathrm{SiOH}} /\left(\mathrm{H}_{2} \mathrm{O}\right)_{\text {sum }} / 100\right) \\
& \cdot\left((0 / \mathrm{OH}) /\left(\mathrm{O}_{2} / \mathrm{SiO}_{2}\left(\mathrm{H}_{2} \mathrm{O}\right)_{0.025}\right)\right. \\
& \times 100=0.132 \%
\end{aligned}
$$

with

$\mathrm{O}_{\text {ex }}$ : exchangeable oxygen $\left(\mathrm{H}_{2} \mathrm{O}\right)_{\mathrm{SiOH}}$ vs. opal CT $\left(\mathrm{SiO}_{2}\left(\mathrm{H}_{2} \mathrm{O}\right)_{0.025}\right)$ oxygen in wt.\%;

$\left(\mathrm{H}_{2} \mathrm{O}\right)_{\text {sum }}$ : sum of $\left(\mathrm{H}_{2} \mathrm{O}\right)_{\mathrm{SiOH}}$ and $\left(\mathrm{H}_{2} \mathrm{O}\right)_{\mathrm{mol}}$ in wt.\% of bulk opal CT 2.5\% (Flörke, 1971);

$\left(\mathrm{H}_{2} \mathrm{O}\right)_{\mathrm{SiOH}} /\left(\mathrm{H}_{2} \mathrm{O}\right)_{\text {sum }}:\left(\mathrm{H}_{2} \mathrm{O}\right)_{\mathrm{SiOH}}$ vs. $\left(\mathrm{H}_{2} \mathrm{O}\right)_{\text {sum }}$ in wt.\%. 3.0\% (this study);

$(0 / \mathrm{OH}): \mathrm{O}$ vs. $\mathrm{OH}$ in wt. $16 / 18=0.88$;

$\mathrm{O}_{2} / \mathrm{SiO}_{2}\left(\mathrm{H}_{2} \mathrm{O}\right)_{0,025}: \mathrm{O}_{2}$ vs. $\mathrm{SiO}_{2}\left(\mathrm{H}_{2} \mathrm{O}\right)_{0,025}$ in wt. $32 / 64.5=0.5$.

If the $\delta^{18} \mathrm{O}$ value of exchangeable oxygen is $-5 \%$ o to $-10 \%$, and that of non-exchangeable oxygen is 25\% (reasonable values for water and authigenic quartz), the $\delta^{18} \mathrm{O}$ value of the bulk cement without any prior equilibration step would be $24.96-24.97 \%$. Thus, exchangeable oxygen lowers bulk value by only $0.03-0.04 \%$. This is less than the analytical error $(0.09 \%$ ). We conclude that it is unnecessary to equilibrate these samples with water of known $\delta^{18} \mathrm{O}$ value prior to isotopic analysis. 


\subsection{Oxygen isotope signature of the silcrete size fractions}

The average $\delta^{18} \mathrm{O}$ values of the $>2 \mu \mathrm{m}$ size fractions range from $12.11 \%$ to $15.36 \%$ (Table 1). As observed in $\mathrm{CL}$, grains extracted from these fractions exhibit some non-luminescing zones, and we assume that the bulk $\delta^{18} \mathrm{O}$ of these fractions reflects a mixture of high temperature, low $\delta^{18} \mathrm{O}$ detrital quartz and low temperature, high $\delta^{18} \mathrm{O}$ overgrowths or remnants of silcrete cement. These measured $\delta^{18} \mathrm{O}$ values are similar to $\delta^{18} \mathrm{O}$ values of bulk sand of the Mirikata Formation (12.9-16.5\%o), overlying the "Cordillo silcretes", and measured by Webb and Golding (1998).

The measured $\delta^{18} \mathrm{O}$ value of the $<2 \mu \mathrm{m}$ size fraction reaches $24.71 \%$ (Table 1). Approximately $96.1 \pm 1.9 \%$ of this fraction is non-luminescent lowtemperature quartz and $3.9 \pm 1.9 \%$ is luminescent high-temperature quartz. The $\delta^{18} \mathrm{O}$ values attributed to detrital igneous or metamorphic quartz range of 6.4-20.0 (Garlick and Epstein, 1967; Savin and Epstein, 1970; Clayton et al., 1972; Eslinger et al., 1973; Blatt, 1986; Graham et al., 1996). Thus, assuming $3.9 \pm 1.9 \%$ of the $<2 \mu \mathrm{m}$ fraction is made of detrital quartz with a $\delta^{18} \mathrm{O}$ value between $6.4 \%$ and $20.0 \%$ yields a corrected $\delta^{18} \mathrm{O}$ value between $24.8 \%$ ond $25.8 \%$ (or $25.3 \% \circ \pm 0.5$ ) for the lowtemperature quartz end member $(96.1 \pm 1.9 \%$ of the $<2 \mu \mathrm{m}$ fraction). These values are in the range of those attributed to authigenic quartz from silicified fossils (19-27\%; Savin and Epstein, 1970) or to quartz overgrowths in sandstones (16.8-26.8\%;
Graham et al., 1996). They are a bit lower than those attributed to quartz from cherts (27-39\%o; Kolodony and Epstein, 1976) and to authigenic quartz precipitated in Haitian regolith (32 $\pm 1 \%$ o, Bird et al., 1992). They are within the range of values estimated for quartz overgrowths from Egyptian silcretes $(20.5 \%$ ond $30.5 \%$; Abdel-Wahab et al., 1998 ) and close to the mean value of $25 \%$ calculated for micro-crystalline quartz of assumed MiocenePliocene age in pedogenic silcretes from Central Victoria (Webb and Golding, 1998).

\section{Discussion}

\subsection{Paleoenvironmental implications of mineralog- ical data}

The massive structure of the silcrete studied here and the absence of pedogenic features such as columnar structure, nodules and clay coatings around detrital quartz, suggest that this silcrete formed by precipitation from groundwater. Chemical composition of the bulk material indicates low salt content (e.g., $\mathrm{Na}_{2} \mathrm{O}$ of $0.001 \%$ ). This argues against an origin of the silcrete from hydrothermal waters, saline groundwater, lakes or swamps affected by strong evaporation. For comparison, inland pedogenic and groundwater silcretes studied by Webb and Golding (1998) have $\mathrm{Na}_{2} \mathrm{O}$ contents ranging from $0.07 \%$ to $1.06 \%$ reflecting concentration by strong evaporation. The dominance of micro- to

Table 1

Oxygen isotope ratio and amount of luminescing detrital quartz grains counted under SEM for the eight silcrete size fractions

\begin{tabular}{|c|c|c|c|c|c|}
\hline $\begin{array}{l}\text { Quartz size } \\
\text { fraction }(\mu \mathrm{m})\end{array}$ & $\begin{array}{l}\text { Measured mean } \\
\delta^{18} \mathrm{O}^{\mathrm{a}}(\% \text { vs. V-SMOW) }\end{array}$ & $n$ & $\begin{array}{l}\text { Standard error }{ }^{\mathrm{b}} \\
\text { (\%o vs. V-SMOW) }\end{array}$ & $\begin{array}{l}\text { SEM-counted luminescing } \\
\text { quartz grains }{ }^{\mathrm{c}}(\%) \text { : mean and } \sigma\end{array}$ & $\begin{array}{l}\text { Corrected } \delta^{18} \mathrm{O}(\% \circ \text { vs. V-SMOW) } \\
\text { of authigenic quartz cement }^{\mathrm{d}}\end{array}$ \\
\hline$>850$ & 15.38 & 2 & 0.03 & & \\
\hline $360-850$ & 14.29 & 2 & 0.16 & & \\
\hline $250-360$ & 12.27 & 2 & 0.11 & & \\
\hline $150-250$ & 12.14 & 1 & & & \\
\hline $63-150$ & 13.3 & 1 & & & \\
\hline $45-63$ & 12.33 & 2 & 0.10 & & \\
\hline $2-45$ & 15.12 & 2 & 0.11 & & \\
\hline$<2$ & 24.71 & 2 & 0.03 & $3.9 \pm 1.9$ & $24.8 / 25.8$ \\
\hline
\end{tabular}

${ }^{\text {a }}$ External reproductibility of the mass spectrometer is \pm 0.05 .

${ }^{\mathrm{b}}$ Replicate analysis yield a standard error lower than 0.11 .

${ }^{c}$ Calculations are based on 5 counting of 154, 86, 80, 61 and 262 particles.

d See text for details of the correction for contamination with detrital quartz. 
crypto-crystalline quartz and overgrowth quartz in the cement strengthens the argument that the parent rock was permeable, of low clay content, permeated by waters with low concentrations of $\mathrm{Si}$ and soluble salts (Callen, 1983). High Si and salt concentrations would have led to the precipitation of opaline silica, which has a solubility $\left(>60 \mathrm{mg} \mathrm{l}^{-1}\right)$ significantly higher than that of micro-crystalline quartz $(<20 \mathrm{mg}$ $\mathrm{1}^{-1}$ ) and chalcedony (20-60 $\mathrm{mg} \mathrm{l}^{-1}$ ) (Thiry and Millot, 1987; Thiry and Milnes, 1991; Williams et al., 1985; Iler, 1979). As noted, sediments underlying and overlying the "Cordillo silcretes" show evidence for permanent drainage systems, supporting the hypothesis that silcrete formation was related to fluctuations of shallow water tables contemporaneous with the slow tectonic uplift of the northern part of the Lake Eyre Basin (Alley, 1998).

\subsection{Paleoenvironmental implications derived from isotope data}

Both the presence of iron oxide coatings on the quartz overgrowths and the occurrence of multiple mineralogical phases of silica within the silcrete cement, suggest variations in fluid composition during cement precipitation. Graham et al. (1996) and Girard et al. (2001) reported spatial variations of several per mil in the $\delta^{18} \mathrm{O}$ values of quartz cement in sandstone, using in situ micro-analyses by secondary ion microprobe. It is possible that isotopic variations exist within the cement concentrate and have not been detected using conventional isotopic analyses. However; it is reasonable to assume that the $<2 \mu \mathrm{m}$ size fraction is preferentially composed of crypto-crystalline quartz because it is more abundant in the bulk and probably more easily freed than the other authigenic quartz. In the discussion of the conditions of cement formation that follows, we take the $\delta^{18} \mathrm{O}$ value of the $<2 \mathrm{~m}$ fraction to represent that of a single formational stage.

Two low temperature quartz-water fractionation factors are commonly used. The quartz-water fractionation factor proposed by Knauth and Epstein (1976) is smaller than that proposed by Matsuhisa et al. (1979) who reassessed the fractionation relationship of Clayton et al. (1972). Because of this disagreement, both fractionation equations were used in our calculations (Fig. 4).

\subsection{Estimate of present-day $\delta^{18} O$ value of the groundwater}

There have been no measurements of the isotopic composition of precipitation at Innamincka. The closest localities for which such data are available are Alice Springs and Adelaide. Of those, the climate at Alice Springs is most similar to that at Oodnadatta, with the rainy season occurring in summer.

The $\delta^{18} \mathrm{O}$ value of precipitation at Alice Springs is probably lower than that at Oodnadatta, as it is at

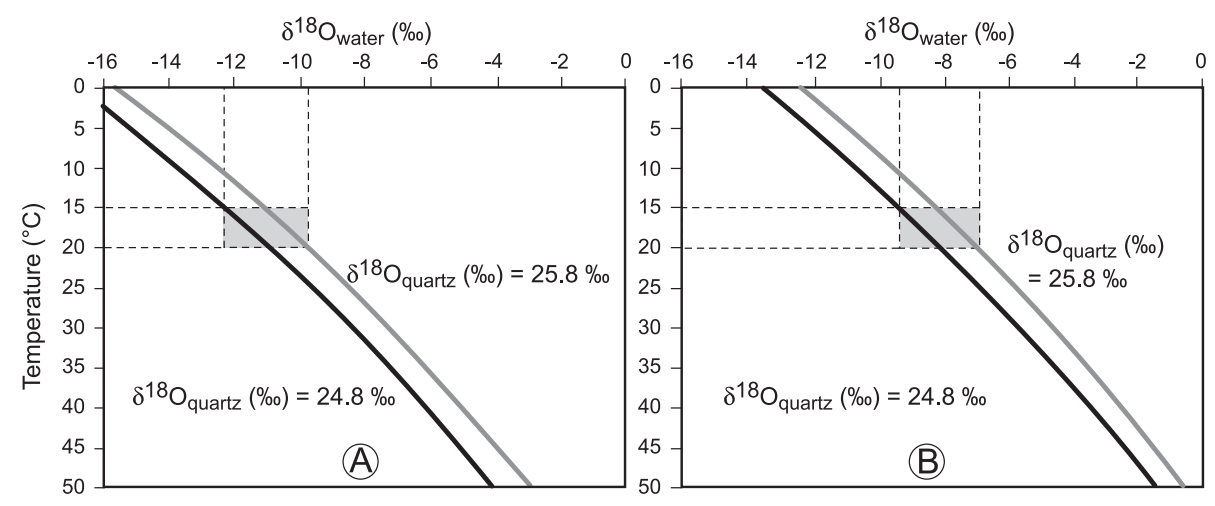

Fig. 4. Calculated oxygen isotopic composition of water in equilibrium with authigenic quartz ranging from 24.8 to $25.8 \%$, as a function of temperature using fractionation factors extrapolated to low temperatures from: (A) $1000 \ln \alpha_{\text {quartz- } \mathrm{H}_{2} \mathrm{O}}=3.34\left(10^{6} T^{-2}\right.$ ) -3.31 (Matsuhisa et al.,

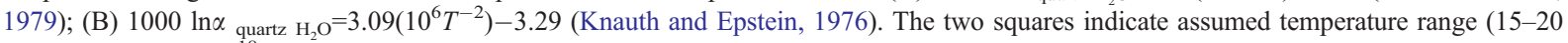
${ }^{\circ} \mathrm{C}$ ) and the related $\delta^{18} \mathrm{O}$ value of water (A: from -12.2 to $-9.8 \%$; $\mathrm{B}$ : from -9.2 to $-6.9 \%$ ), from which authigenic quartz precipitated. 
higher elevation (Alice Springs: $548 \mathrm{~m}$ a.s.l.; Oodnadatta: $116 \mathrm{~m}$ a.s.l.), is colder (mean annual temperature at Alice Springs: $18-21{ }^{\circ} \mathrm{C}$; at Oodnadatta: $21-24{ }^{\circ} \mathrm{C}$ ), and wetter (mean annual rainfall at Alice Spring: $671 \mathrm{~mm}$; at Oodnadatta: $398 \mathrm{~mm}$ ) (Australian Bureau of Meteorology, 2001), thus less intensely evaporative. The weighted mean $\delta^{18} \mathrm{O}$ value of precipitation at Alice Springs is $-6.70 \%$ o (Rozanski et al., 1993).

Besides, $\delta^{18} \mathrm{O}$ values of groundwater episodically recharged during summer months may be higher than that of summer precipitation, due to evaporation, and thus higher than that of annual precipitation.

Thus, it is reasonable to assume that the value of $-6.70 \%$ represents a minimum $\delta^{18} \mathrm{O}$ value for present-day groundwaters at Oodnadatta and by further extrapolation, at Innamincka. This is consistent with $\delta^{18} \mathrm{O}$ values ranging from $-4.5 \%$ o to $-5.5 \pm 0.15 \%$ o measured in fractured rock aquifers, in the Stephens Creek catchment near Broken Hill, New South Wales, $500 \mathrm{~km}$ south of Innamincka (Fig. 1) (Dann, 2001).

\subsection{Paleotemperatures at Innamincka used for infer- ring $\delta^{18} \mathrm{O}$ of paleo-groundwater}

We assume that temperatures of shallow groundwater from which silcrete cement may have precipitated were in the same range as air temperatures for the following reasons: petrographic features ruled out hypothesis of ascending basinal brines (Alley, 1998) and conditions wetter than those of the present day prevailed (Alley, 1998; Greenwood, 1994; Wopfner, 1978; Martin, 1990).

Paleo-geographic reconstructions indicate a paleolatitude between $52^{\circ} \mathrm{S}$ (ca. $45 \mathrm{Ma}$ ) and $41^{\circ} \mathrm{S}$ (ca. 25 Ma) (Veevers, 1984; Li and Powell, 2001), and a continental mean annual temperature of $15-20{ }^{\circ} \mathrm{C}$ between $50^{\circ} \mathrm{S}$ at $45 \mathrm{Ma}$ and $40^{\circ} \mathrm{S}$ at $25 \mathrm{Ma}$ (Savin, 1977; Frakes et al., 1994; Frakes et al., 1994; Greenwood and Wing, 1995; Alley, 1998; McGowan and Li, 1998). These studies argue for a climate slightly colder and much wetter than today in Central Australia.

The calculated $\delta^{18} \mathrm{O}$ value of water from which quartz ( $\delta^{18} \mathrm{O}$ between $24.8 \%$ and $25.8 \%$ ) formed at a temperature of $15-20{ }^{\circ} \mathrm{C}$ would be between $-6.9 \%$ o and $-12.2 \%$ (depending on fractionation equation used) (Fig. 4). These values are lower than the minimum $\delta^{18} \mathrm{O}$ value of $-6.70 \%$ ostimated for the modern groundwater at the sample site.

\subsection{Paleoenvironmental interpretation}

The lower $\delta^{18} \mathrm{O}$ value of Eocene/Oligocene silcrete-forming water than of modern water may reflect the following:

- The ${ }^{18} \mathrm{O}$-depleted nature of the pre-glacial ocean (Shackleton and Kennett, 1975).

- An Eocene/Oligocene climate that was more monsoon-like than present-day climate in this part of Australia (Alley, 1998). Convective systems such as monsoonal rains are associated with a decrease in $\delta^{18} \mathrm{O}$ values of precipitation, particularly at temperatures higher than $15{ }^{\circ} \mathrm{C}$ (Joussaume et al., 1984; Rozanski et al., 1993; Fricke and O'Neil, 1999). In this case, a mean annual rainfall of $1400 \mathrm{~mm}$, as inferred from pollen and macro-rests from the Eyre formation (Croke et al., 1998), would suggest a monsoonal decrease in $\delta^{18} \mathrm{O}$ of meteoric waters, and hence groundwaters, of several per mil.

- Less intense evaporation at the site during Eocene/Oligocene time than at present or other local meteorologic factors. Paleoenvironmental reconstructions (Alley, 1998) suggest Lake Eyre Basin supported permanent drainage systems, consistent with conditions significantly wetter than those of the present day. Thus, provided that the Eocene/Oligocene groundwaters were shallow and rapidly recharged, they would have been depleted in ${ }^{18} \mathrm{O}$ by several per mil relative to the modern ones, which are more subject to evaporation.

- Error in the estimate of the $\delta^{18} \mathrm{O}$ values of modern groundwater at the sample locality.

Uncertainties in the paleoclimatic interpretation are related to ambiguities in the relationship between climate and the $\delta^{18} \mathrm{O}$ value of groundwater, the limitations imposed by the analysis of only a single cement sample, the possibility of isotopic heterogeneity within the cement and the lack of knowledge of the precise timing of the cementation process. In spite of that, however, a plausible paleoenvironmental scenario may be based upon 
the data of this study and the recent syntheses of Alley (1998) and Croke et al. (1998). In this scenario, during the most probable time of silcrete formation, the Basin experienced a monsoon-like climate, with mean temperature of precipitation between 15 and $20{ }^{\circ} \mathrm{C}$. The abundant precipitation gave rise to permanent drainage systems in the Lake Eyre Basin. The development of a lacustrine environment was related to the onset of monsoonlike conditions as well as epeirogenic uplift (Croke et al., 1998) that may have led to significant water table fluctuations (Alley, 1998; Croke et al., 1998). We speculate that the different mineralogical phases of the silcrete cement may have been related to gradual or successive water table fluctuations.

\section{Conclusion}

The chemically facilitated separation of authigenic quartz from the detrital quartz of a silcrete sample belonging to the Late Eocene/Oligocene "Cordillo silcrete" group allowed us to directly measure the oxygen isotopic composition of the silcrete cement by conventional analytical procedures. This avoids the errors inherent in previous studies of silcrete, in which the isotopic composition of cement was estimated from isotopic analyses of bulk material and mass balance considerations.

The massive structure and the absence of pedogenic features suggest that this silcrete formed through precipitation from groundwater.

Petrographic, mineralogical and FT-IR data showed three phases of cement: (i) overgrowth; (ii) crypto-crystalline quartz; and (iii) micro-crystalline quartz. These different mineralogical phases are the result of multiple phases of cement formation. Although mainly made of crypto-crystalline quartz the $\delta^{18} \mathrm{O}$ value of the silcrete cement must be interpreted as an average of $\delta^{18} \mathrm{O}$ value of the three phases resulting from gradual or discrete changes in the nature of the cement-forming fluids, most likely related to water table fluctuation.

FT-IR analyses of the hydrated opal-CT allowed us to estimate the percentage of $\mathrm{Si}-\mathrm{OH}$-exchangeable oxygen in the silcrete cement. As it represents only $0.132 \%$ of the oxygen of the silcrete cement, and lowers bulk value by less than the analytical error $(0,09)$ it was not necessary to equilibrate the sample with water of known isotopic composition prior to isotopic analysis, in order to obtain reliable $\delta^{18} \mathrm{O}$ values. This conclusion cannot be extended to other samples without checking.

The average $\delta^{18} \mathrm{O}$ value of the cement sample is between $24.9 \%$ and $25.7 \%$. No matter what quartzwater equilibrium fractionation equation is used, and assuming an Eocene/Oligocene temperature of 15-20 ${ }^{\circ} \mathrm{C}$, consistent with published paleotemperature estimates, the inferred $\delta^{18} \mathrm{O}$ values of the cementforming solutions ranged from $-6.9 \%$ o to $-12.2 \%$. These values are lower than the minimum $\delta^{18} \mathrm{O}$ value of $-6.70 \%$ estimated for modern groundwater near the sample site. This difference may be understood using paleoenvironmental reconstructions proposed by Alley (1998) and Croke et al. (1998): silcrete may have formed from shallow groundwater, frequently recharged in a climate colder and wetter than the modern one. Water table fluctuations important to the formation of the cement probably resulted from the onset of monsoon-like conditions and slow tectonic uplift, leading to a change from fluvial to lacustrine conditions.

In order to test our hypothesis, several additional lines of evidence are needed:

- Further constraints on the time of silcrete cementation are necessary in order to more precisely constrain climatic conditions under which the secondary quartz precipitated from saturated groundwater.

- Additional samples from the "Cordillo silcrete" group need to be analyzed.

- Isotopic analyses of each of the three cement phases of the same silcrete sample using the ion microprobe, or using conventional analysis of size fractions smaller than $2 \mu \mathrm{m}$, would further clarify the evolution of conditions leading to the silcrete cement deposition.

\section{Acknowledgement}

This work was started during post-doctoral training of A.A. at the Stable Isotope Lab of the Department of Geological Sciences of Case Western Reserve University (CWRU, Cleveland, OH, USA). 
A.A. was supported by a "Lavoisier" grant allocated by the French "Ministère des Affaires Etrangères".

We thank Linda Abel for her precious help in the Stable Isotope Lab at CWRU.

We thank C. France-Lanord who made the conventional silicate line of the CRPG (Nancy, France) available to us and P. Coget and C. Guillemette for their assistance with extraction and analysis of the stable isotopes of oxygen at the CRPG.

We thank P. Karcher and F. Diot for their help in acquiring the CL images, respectively at the Geology Institut of Strasbourg, and at the University of Nancy I, O. Grauby (CRMC2, Marseille, France) for preparation of the FT-IR samples, J. Klister, J. Lamontagne for their help in acquiring the FTIR data at the University of Aix-Marseille III (France) and J.J. Motte (CEREGE, France) who provided drawing support. We appreciate the very helpful reviews by Drs. Libby Stern and Jean-Pierre Girard of an earlier version of this manuscript. This study was supported by the French program PROSE and a grant from NSF (USA). Fieldwork was supported by the cooperative Research Centre for Landscapes, Environments and Mineral Exploration (CRC LEME, Australia). [LW]

\section{References}

Abdel-Wahab, A., Salem, A.M.K., McBride, E.F., 1998. Quartz cement of meteoric origin in silcrete and nonsilcrete sandstones, Lower Carboniferous, Western Sinai, Egypt. J. Afr. Earth Sci. 27-2, 277-290.

Alley, N.F., 1998. Cainozoic stratigraphy, palaeoenvironments and geological evolution of the Lake Eyre Basin. Palaeogeogr. Palaeoclimatol. Palaeoecol. 144, 239-263.

Australian Bureau of Meteorology, 2001. http://www.bom.goau.

Barres, O., 1990. Applications de la spectrométrie infrarouge à transformée de Fourier pour l'analyse microscopique des inclusions fluides à hydrocarbures et l'étude de surface de poudres de silice. PhD thesis, University of Nancy 1.

Blatt, H., 1986. Oxygen isotopes and the origin of quartz. J. Sediment. Petrol. 57-2, 373-377.

Bird, M.I., Longstaffe, F.J., Fyfe, W.S., Bildgen, P., 1992. Oxygenisotope systematics in a multiphase weathering system in Haiti. Geochim. Cosmochim. Acta 56, 2831-2838.

Callen, R.A., 1983. Late Tertiary 'grey billy' and the age and origin of surficial silicifications (silcrete) in South Australia. J. Geol. Soc. Aust. 30, 393-410.
Canals, M., Meunier, J.D., 1995. A model for porosity reduction in quartzite reservoirs by quartz cementation. Geochim. Cosmochim. Acta 59-4, 699-709.

Chadwick, O.A., Hendricks, D.M., Nettleton, W.D., 1987. Silica in duric soils: II. Mineralogy. Soil Sci. Soc. Am. J. 51-4, 982-985.

Clayton, R.N., Mayeda, T.K., 1963. The use of bromine pentafluorine in the extraction of oxygen from oxides and silicates for isotopic analysis. Geochim. Cosmochim. Acta 27, 43-52.

Clayton, R.N., O’Neil, J.R., Mayeda, T.K., 1972. Oxygen isotope exchange between quartz and water. J. Phys. Res. 77-17, 3057-3067.

Christophel, D.C., Greenwood, D.R., 1989. Changes in climate and vegetation in Australia during the Tertiary. Rev. Palaeobot. Palynol. 58, 95-109.

Croke, J.C., Magee, J.M., Price, D.M., 1998. Stratigraphy and sedimentology of the lower Neales River, West Lake Eyre, Central Australia: from Palaeocene to Holocene. Palaeogeogr. Palaeoclimatol. Palaeoecol. 144, 331-350.

Dann, R., 2001. Hydrogeochemistry and biogeochemistry in the Stephens Creek catchment, Broken Hill, New South Wales. Honours in Applied Science thesis, Cooperative Centre for Landscape Environments and Mineral Exploration, University of Canberra.

Eslinger, E., Mayer, L.M., Durst, T.L., Hower, J., Savin, S.M., 1973. An X-ray technique for distinguishing between detrital and secondary quartz in the fine-grained fraction of sedimentary rocks. J. Sediment. Petrol. 43-2, 540-543.

Flörke, O.W., Graetsch, H., Martin, B., RûÑller, K., Wirth, R., 1991. Nomenclature of micro- and non-crystalline silica minerals, based on structure and microstructure. Neues Jahrb. Mineral. Abh. 163-1, 19-42.

Frakes, L.A., Probst, J.L., Ludwig, W., 1994. Latitudinal distribution of paleotemperature on land and sea from early Cretaceous to middle Miocene. Compte Rendus de l'Acadû̀mie des Sciences Paris 318-II, 1209-1218.

Fricke, H.C., O'Neil, J.R., 1999. The correlation between ${ }^{18} \mathrm{O} /{ }^{16} \mathrm{O}$ ratios of meteoric water and surface temperature: its use in investigating climate change over geologic time. Earth Planet. Sci. Lett. 170, 181-196.

Garlick, G.D., Epstein, S., 1967. Oxygen isotope ratios in coexisting minerals of regionally metamorphosed rocks. Geochim. Cosmochim. Acta 31, 181-214.

Girard, J.-P., Deynoux, M., 1991. Oxygen isotope study of digenetic quartz overgrowths from the Upper Proterozoic quartzites of western Mali, Taoudeni Basin: implications for conditions of quartz cementation. J. Sediment. Petrol. 61-3, 406-418.

Girard, J.-P., Munz, I.A., Johansen, H., Hill, S., Canham, A., 2001. Conditions and timing of quartz cementation in Brent reservoirs, Hild Field, North Sea: constrains from fluid inclusions and SIMS oxygen isotope microanalysis. Chem. Geol. 176-1-4, 73-92.

Graham, C.M., Valley, J.W., Winter, B.L., 1996. Ion microprobe analysis of ${ }^{18} \mathrm{O} /{ }^{16} \mathrm{O}$ in authigenic and detrital quartz in the St. Peter Sandstone, Michigan Basin and Wisconsin Arch, USA: contrasting diagenetic histories. Geochim. Cosmochim. Acta 60-24, 5101-5116. 
Greenwood, D.R., 1994. Palaebotanical evidence for Tertiary climates. In: Hill, R.S. (Ed.), The History of Australian Vegetation, vol. 433. Cambridge Univ. Press, pp. 44-59.

Greenwood, D.R., Wing, S.L., 1995. Eocene continental climates and latitudinal temperature gradients. Geology 23-11, 1044-1048.

Haimson, M., Knauth, L.P., 1983. Stepwise fluorinationã a useful approach for the isotopic analysis of hydrous minerals. Geochim. Cosmochim. Acta 47, 1589-1595.

Hutton, J.T., Twidale, C.R., Milnes, A.R., 1978. Characteristics and origin of some Australian silcretes. In: Langford-Smith, T. (Ed.), Silcrete in Australia. University of New England, Australia, pp. 19-40.

Iler, R.K., 1979. The surface chemistry of silica. The Chemistry of Silica. Wiley, New York, pp. 623-729.

Jones, J.B., Segnit, E.R., 1971. The nature of opal: I. Nomenclature and constituent phases. J. Geol. Soc. Aust. 18-1, 57-68.

Joussaume, S., Sadourny, R., Jouzel, J., 1984. A general circulation model of water isotope cycles in the atmosphere. Nature 311, 24-29.

Knauth, L.P., Epstein, S., 1976. Hydrogen and oxygen isotope ratios in nodular and bedded cherts. Geochim. Cosmochim. Acta 40, $1095-1108$.

Kolodony, Y., Epstein, S., 1976. Stable isotope geochemistry of deep sea cherts. Geochim. Cosmochim. Acta 40, 1195-1209.

Labeyrie, L., Juillet, A., 1982. Oxygen isotopic exchangeability of diatom valve silica; interpretation and consequences for paleoclimatic studies. Geochim. Cosmochim. Acta 46, 967-975.

Langer, K., Flörke, O.W., 1974. Near infrared absorption spectra (4000-9000 $\mathrm{cm}^{-1}$ ) of opals and the role of "water" in these $\mathrm{SiO}_{2}$ $n \mathrm{H}_{2} \mathrm{O}$ minerals. J. Am. Chem. Soc. 62, 1168-1178.

Langford-Smith, T., 1978. A select review of silcrete research in Australia. In: Langford-Smith, T. (Ed.), Silcrete in Australia. University of New England, Australia. 304 pp.

Lee, M., Savin, S.M., 1985. Isolation of digenetic overgrowths on quartz sand grains for oxygen isotopic analysis. Geochim. Cosmochim. Acta 49, 497-501.

Li, Z.X., Powell, C.McA., 2001. An outline of the palaeogeographic evolution of the Australasian region since the beginning of the Neoproterozoic. Earth-Sci. Rev. 53, 237-277.

Llorens, E., 1999. Origine des silcretes: apport de la micromorphologie (imagerie et cathodoluminescence) et de la micro-spectromû̀trie IR û transformû̀e de Fourier. Mû̀moire de DiplûÇme d'Etudes Approfondies (Master thesis French equivalent), Universitû̀ Aix-Marseille III. 35 pp.

McGowan, B., Li, Q., 1998. Cenozoic climatic change and its implication for understanding the Australian regolith. The state of the regolith. Spec. Publ.-Geol. Soc. Aust. 20, 86-103.

Martin, H.A., 1990. Tertiary climate and phytogeography in southeastern Australia. Rev. Palaeobot. Palynol. 65, 47-55.

Matsuhisa, Y., Goldsmith, J.R., Clayton, R.N., 1979. Oxygen isotopic fractionation in the system quartzã albiteã anorthiteã water. Geochim. Cosmochim. Acta 43, 1131-1140.

Nash, D.J., Thomas, D.S.G., Shaw, A., 1994. Siliceous duricrusts as palaoeclimatic indicators: evidence from Kalahari Desert of Botswana. Palaeogeogr. Palaeoclimatol. Palaeoecol. 112, $279-295$.
Pironon, J., Meunier, J.D., Alexandre, A., Mathieu, R., Mansuy, L., Grosjean, A., Jarde, E., 2001. Individual characterization of phytoliths: experimental approach and consequences on paleoenvironment understanding. In: Meunier, J.D., Colin, F. (Eds.), Phytoliths: Applications in Earth Sciences and Human History. A.A. Balkema, Lisse, pp. 329.

Rodas, M., Luque, F.J., Mas, R., Garzon, M.G., 1994. Calcretes, palycretes and silcretes in the Paleogene detrital sediments of the Duero and Tajo basins, Central Spain. Clay Miner. 29, $273-285$.

Ross, G.M., Chiarenzelli, J.R., 1985. Paleoclimatic significance of widespread proterozoic silcretes in the Bear and Churchill Provinces of the Northwestern Canadian shield. J. Sediment. Petrol. 55-2, 196-204.

Rozanski, K., Araguas-Araguass, L., Gonfiantini, R., 1993. Isotopic patterns in modern global precipitation. Climate change in continental isotopic records. Geophys. Monogr. 78, 1-36.

Savin, S.M., 1977. The history of the earth's surface temperature during the past 100 million years. Annu. Rev. Earth Planet. Sci. 5, 319-355.

Savin, S.M., Epstein, S., 1970. The oxygen isotopic compositions of coarse grained sedimentary rocks and minerals. Geochim. Cosmochim. Acta 34, 323-329.

Shackleton, N.J., Kennett, J.P., 1975. Paleotemperature history of the Cenozoic and the initiation of Antarctic glaciation: oxygen and carbon isotope analyses in DSDP Sites 277, 279, and 281. Kennett, J.P., Houtz, R.E., et al., Init. Repts. DSDP vol. 29. U.S. Government Printing Office, Washington, pp. 743-755.

Singh, B., Gilkes, R.J., Butt, C.R.M., 1992. An electron optical investigation of aluminosilicate cements in silcretes. Clays Clay Miner. 40-6, 707-721.

Smale, D., 1973. Silcretes and associated diagenesis in Southern Africa and Australia. J. Sediment. Petrol. 43-4, 1077-1089.

Sprunt, E.S., Nur, A., 1981. Causes of quartz cathodoluminescence color. Scanning Electron Microsc. 1, 525-535.

Summerfield, M.A., 1983. Petrography and diagenesis of silcrete from the Kalahari Basin and Cape coastal zone, Southern Africa. J. Sediment. Petrol. 53-3, 895-909.

Summerfield, M.A., 1983. Silcrete as a paleoclimatic indicator: evidence from Southern Africa. Palaeogeogr. Palaeoclimatol. Palaeoecol. 41, 65-79.

Taylor, G., Ruxton, B.P., 1987. A duricrust catena in Southeast Australia. Z. Geomorphol. 31-4, 385-410.

Thiry, M., Millot, G., 1987. Mineralogical forms of silica and their sequence of formation in silcretes. J. Sediment. Petrol. 57-2, $343-352$.

Thiry, M., Milnes, A.R., 1991. Pedogenic and groundwater silcretes at Stuart Creek Opal Field, South Australia. J. Sediment. Petrol. 61-1, 111-127.

Thiry, M., Simon-Coinçon, R., 1996. Tertiary paleoweatherings and silcretes in southern Paris Basin. Catena 26, 1-26.

Veevers, J.J. (Ed.), Phanerozoic Earth History of Australia. Clarendon Press, Oxford, England. 418 pp.

Watchman, A.L., Twidale, C.R., 2002. Relative and 'absolute' dating of land surfaces. Earth-Sci. Rev. 58, 1-49.

Watts, S.H., 1978. The nature and occurrence of silcrete in Tibooburra Area of Northwestern New South Wales. In: 
Wopfner, H. (Ed.), Silcrete in Australia. University of New England, Australia. pp. 304. 167-193.

Webb, J.A., Golding, S.D., 1998. Geochemical mass-balance and oxygen-isotope constraints on silcrete formation and its paleoclimatic implications in Southern Australia. J. Sediment. Res. 68-5, 981-993.

Webb, E.A., Longstaffe, F.J., 2000. The oxygen compositions of silica phytoliths and plant water in grasses: implication for the study of paleoclimate. Geochim. Cosmochim. Acta 64-5, $767-780$.

Williams, L.A., Parks, G.A., Crerar, D.A., 1985. Silica diagenesis: I. Solubility controls. J. Sediment. Petrol. 55-3, 301-311.

Wopfner, H., 1978. Silcretes of northern South Australia and adjacent regions. In: Langford-Smith, T. (Ed.), Silcrete in Australia. University of New England, Australia. pp. 304. 93-141. 